\title{
Social Conservatives' Adoption of a Subaltern Discourse After the 2012 US Presidential Election
} Kevin Frazier*, Economics

\begin{abstract}
Mitt Romney's defeat in the 2012 Presidential Election led to rampant speculation, both within and outside of the Republican Party, that President Obama's victory required the GOP to re-evaluate its platform, leaders, and future. Some groups amongst the Republican coalition, specifically the Evangelical Christians, believe the electoral loss carries deeper meaning. They see the Democratic Party's general success as a sign of America being 'lost'. In response to the election, Evangelicals have formed a counter-public based on a narrative of defeat to increase its cohesiveness thus defining its political identity. Beyond politically defining Evangelical Christians, this report will inspect Pastors' speeches, TV personalities' testimonies, newspaper editorials, and previous studies regarding the 2012 election and stances on relevant issues to determine who is promoting this idea of a 'lost' America and why they stubbornly maintain this sentiment. Consideration of Evangelical sources will highlight their reasons for increasingly feeling morally threatened and politically trapped. While previous works have stressed the power held by Evangelical groups, this study will analyze the narrative giving them their influence.
\end{abstract}

\section{INTORDUCTION}

After the 2012 US Presidential election, an unexpectedly large victory by President Barack Obama sparked a Republican internal investigation into the causes of their political defeat. The official 'autopsy' report produced by the Republican National Committee identified several policy stances that required a reform. The Party's positions on social issues, for example, have been questioned. More specifically, many have demanded a shift away from conservative beliefs regarding hot-button social items such as abortion and gay marriage. Previously considered one of the strengths of the party, the evangelical or socially conservative wing of the Republican coalition has been alienated as a result of their stubborn adherence to strict moral principles amidst a wave of secularization. Thus, the majority of evangelicals, when regarded as a political entity, have become a subculture defined by both a narrative of defiance to policy changes and by a narrative based on America's moral defeat. However, those who identify with the faction dispute any notion that suggests the social conservatives have embraced a subordinate position within the Republican Party. This stance contradicts at least one definition of a counterpublic. Citing their historical political significance to the GOP, notable socially

\footnotetext{
*Kevin Frazier, a sophomore Economics major, is a native Oregonian who has a passion for civic engagement. His desire to participate in the political process has spurred him to intern with Secretary of State Kate Brown and US Senator Jeff Merkley. Presently, Kevin is the President of the College Democrats of Oregon and the Student Representative on the Oregon Bicycle and Pedestrian Advisory Committee. Correspondingly, he hopes to attend law school and work in the Civil Rights Division of the Department of Justice. Please send correspondence to kevintfrzier@gmail.com.
} 
conservative figures demand recognition of their ideals in the platform or threaten the creation of a new party. By means of studying firsthand accounts from pastors, TV personalities, and politicians this study will politically define this counterculture. Then, it will analyze its leaders, their narratives, and the effects induced by these messages on their electoral standing.

\section{METHODOLOGY}

Analysis of the media produced by the Religious Right reveals their similarities to a counterculture, as defined by Michael Warner. Unlike other papers, this study will view the social conservatives as more than just a political faction. Utilizing Warner's perception of a counterculture, one begins to see how the evangelicals closely meet his model. In the same way, while others focus on the day-by-day messaging conveyed by the 24-hour news cycle, consideration of the group's narratives as a whole will be taken into account. The inclusion of eclectic sources - debate transcripts, editorials, TV show segments, and Ministers' emails further distinguishes this paper from other documents. As an author of Publics and Counterpublics, Warner stresses three points when defining a counterpublic: the circulation of texts, the tension with the larger public, and the idea of being cognizant of their subordination. ${ }^{1}$ Although the social conservatives' adoption of a subaltern discourse adheres to the first two requirements assigned by Warner, only a small portion of this unit has embraced the idea of being an inferior body. As previously stated, throughout the post-election turmoil eminent social conservatives have maintained a narrative of opposition to policy shifts and a narrative rooted in America's decreasing respect for Christian principles. Defining the sources of and motivations for these messages will be the primary focus of this paper. Nevertheless, the paper will also expose how the majority of the GOP's most traditional members refuse to accept the subordination clause included in Warner's definition of a counterpublic. Numerous accounts suggest that one division feels that the evangelicals have already passed their political prime and will continue to have increasingly less influence. This sentiment, which aligns with Warner's vision of counterpublics, stands in stark contrast to the rest of the social conservatives who still feel they possess political power.

\section{HOW SOCIAL CONSERVATIVES COMPARE TO WARNER'S DEFINITION}

Contrary to Warner's idea that countercultures acknowledge their secondary position, many of the most influential social conservatives feel they still have the ability to significantly impact the political sphere. Their denial, however, has only strengthened the group's resolve and unity. Abstaining from change has given the social conservative movement more power by further detaching them from the main Republican bloc. Admonishment by the leadership of the Republican Party has failed to produce the desired changes in the social conservatives' beliefs. Subsequently, the narrative of a 'lost' America and of adamant conservatism preached by various leaders has expedited the development of a social conservative counterculture. According to Warner, a counterpublic is at least partially defined by its tension with the larger public and is "mediated by print, theater, diffuse networks of talk, commerce, and the like."2 Media produced by the faction confirms that social conservatives meet these two characteristics. Consideration of the thousands of Megachurches, the plethora of talk radio channels, and of the ever-expanding reach of TV programs all devoted to the social conservative cause makes it clear how such a united, identifiable counterpublic has been formed. Such a large media empire 
allows for the diffusion of communication necessitated by Warner's interpretation. Likewise, Christian groups' feelings of oppression as a result of general condemnation for views deemed as insensitive speak to their identification as a group with plenty of external tension. To Nancy Fraser, the social conservatives likely resemble a "subaltern counterpublic" where "members of subordinated social groups invent and circulate counterdiscourses to formulate oppositional interpretations of their identities, interests, and needs."3 Fraser denotes the centrality of counterdiscourses to counterpublics - a theme that will be appearing frequently below. While one could debate exactly which term best defines the movement, it seems clear the social conservatives represent a subset of the public committed to an alternative ideology. Even so, Warner's instance on counterpublic subordination means his definition fails to entirely embody this group. Both the narratives shared via and the actions taken by Religious Right organizers emphasize the political power and internal solidarity generated by denying subordinate status. Their collective action at the polls as well as their commitment to consuming and sharing media that propagates the narratives of both American moral defeat and defiance to change has sufficiently severed ties with the majority of the population. In the same way, the social conservatives' denial of a lesser role in the GOP has bolstered the group's identity as a counterpublic.

\section{THE DEMOGRAPHICS OF SOCIAL CONSERVATIVES}

Demographics taken from election results, census data, and Pew Polls suggest this counterpublic does wield considerable influence. These results further detach the social conservatives from Warner's idea of subordinate status. Modern media has labeled this political counterculture as the 'social conservatives': a term, which primarily encompasses those within the evangelical sect of Christianity as well as people against progressive positions on social issues. Others frequently use the term 'Religious Right' to refer to the same movement. Election data provide a relatively clear picture on how social conservatives vote and who represents a part of their constituency. According to The Economist, over half of Republicans identify as evangelical but not all of these voters belong in the 'social conservative' category. Amongst those labeled as evangelicals in exit polls, 44 percent of those under the age of 40 defined their social views as 'liberal.'4 Hence, not all evangelicals, especially younger members, are a part of the movement. Additionally, the group appears to have limited participation by non-white evangelicals. Immigration has increasingly led to the inclusion of minorities in evangelical counts, which has dramatically altered the demographics of the sect. Once again the electoral results make the exact delineations more explicit. Analysis of Protestants' votes, of which evangelicalism resides within, confirms the need to include race when defining social conservatives. Approximately 90 percent of black Protestants voted for Obama, in stark contrast to the 70 percent of white Protestants who supported Romney. 5 The Pew Research Center data from May 2011 includes the following demographical breakdown of those who view themselves as staunch conservatives: 56 percent male, eight percent under the age of 30, 31 percent between the ages of 30 and 49, 61 percent over the age of 50, and 92 percent white. In terms of geography, 38 percent of staunch conservatives reside in the South. ${ }^{6}$ Unfortunately, this report does not directly distinguish between staunch fiscal and staunch social conservatives. Gallup poll data from May 2012 suggests economically conservative citizens do not necessarily possess socially conservative views as well. Poll results show 38 percent of Americans identify as total 
social conservatives while 46 percent view themselves as economically conservative. 7 As a consequence, the Pew statistics only provide a general idea of the make-up of the social conservative movement. In terms of geography though, a different Pew survey demonstrates the prevalence of the 'Evangelical Protestant Tradition' in Southern states. For example, over 51 percent of US adults in Oklahoma, Arkansas, and Tennessee view themselves as part of the evangelical movement. ${ }^{8}$ These figures confirm the group's Southern orientation. Data compiled for the spring 2008 primaries demands that one additionally considers religious traditionalism. Clear differences can be seen in Protestants' positional stances based on whether they identify as traditionalists, centrists, or modernists. For example, when asked if same-sex marriage should be legal, nine percent of traditionalists agreed, 26 percent of those in the center assented, and 42 percent of modernists supported the initiative. 9 Despite the age of this survey, religious traditionalism must factor into a definition of social conservatism. Above all else, the election results highlight the uniformity of the social conservatives. This collection of individuals displayed remarkable solidarity in the 2012 Presidential election as 80 percent of white evangelicals voted for Mitt Romney. ${ }^{10}$ In summary, the social conservative movement predominantly comprises elderly, Republican, white, traditionalist or centrist Protestants (especially evangelicals), who likely reside in the South, and may or may not hold economically conservative values as well. For comparison, Robert Jones, in his book Progressive and Religious, defines the Christian Right as "...a fairly homogeneous group dominated by white evangelical Protestants concentrated in the South and Midwest..." 11 Both definitions highlight the significance of age, religion, and geography when defining the faction. Additionally, each definition provides evidence that urges one to view the social conservatives as a counterpublic due to their lack of diversity and general exclusiveness.

\section{HISTORY OF THE FACTION}

After becoming nationally relevant, cohesiveness during elections has, to this day, led to social conservatives shedding the subordinate status associated with most counterpublics. In the past, the faction likely yield greater influence on national campaigns but now, they possess the ability to shape Republican races. Prior to the 1980 s, a period in which several national figures utilized their close ties with the social conservatives to propel themselves into office, Ed Dobson, an evangelical pastor, said, "Evangelicals were considered obscurantist, sweat-drenched Appalachian hillbillies.” However, as Frank Lambert notes in Religion in American Politics, "Though fundamentalists had been barely visible in national public affairs over the previous several decades, they had been far from idle." ${ }^{12}$ Support from Ronald Reagan, during his campaign and after he assumed the Presidency, and the apparent secularization of the American government, as reportedly evidenced by the Roe v. Wade ruling, led to evangelical leaders using their pulpit politically. GOP leaders sought to organize these social conservatives to broaden their coalition, as many of them had previously voted for Democrats. ${ }^{13}$ "The basis for the coalition," according to Kenneth Wade, author of Politics and Religion, "would be a frontal attack on 'big government' as a threat to the traditional religious and economic values." ${ }^{14}$ After initially dealing with politics at the national level, the social conservative movement gained immense power through the implementation of an extensive grassroots network. ${ }^{15}$ However, by the 2012 election cycle, the movement had reached its zenith in terms of national sway. Jeff Zeleny of The New York Times detailed in his article "Iowa May Turn G.O.P.'s Focus to Social 
Issues" how the social conservative movement's focus on social issues in a time of economic uncertainty threatened to get Republican Presidential candidates off-message. Zeleny summarizes:

social and religious conservatives are pressing the likely candidates on issues like same-sex marriage and abortion rather than on jobs, the budget deficit and other economic concerns that leaders of both parties expect to dominate the general election. ${ }^{16}$

Similar articles stressing the social conservative movement's stubborn refusal to ignore social issues occurred frequently in newspapers across the nation prior to the election. A Gallup poll from October 10 demonstrates how the social conservatives' failure to be flexible has led to their isolation both nationally and within the Republican Party. Only 44 percent of Americans thought the government "should promote traditional values in our society." Within the Republican Party, 65 percent denoted their desire for traditional values - down from 79 percent in 2004. ${ }^{17}$ So although this section of the GOP has become less dominant in determining general elections, the subaltern counterpublic has perpetuated its pull in Republican primary elections.

\section{'TENSION WITHIN THE LARGER PUBLIC' FOLLOWING THE 2012 ELECTION}

Social conservatives, as seen by their narratives and population data, undoubtedly adhere to the section of Warner's definition that couples counterpublics to tension with society at large. Evidence from polls and the election show an electorate embracing secular beliefs. Such a transition has motivated the Republican Party leadership to question if the social conservatives still have a place within their party. Months prior to the 2012 election, a USA Today survey found "only 38 percent of the registered voters said social issues like gay marriage and abortion are extremely or very important to them in the context of the presidential campaign." 18 Statistics like these, in addition to Romney's loss, sparked the generation of an election autopsy report. A five-member panel of the Republican National Committee created the document, titled "The Growth and Opportunity Project." Released in December, the project outlined potential changes to the Republican platform to improve its relationship with a diversifying electorate. Included changes such as a more favorable stance on immigration, consideration of maneuvering on gay marriage, and several alterations to the Presidential primary procedure have been widely regarded as attempts to marginalize the social conservatives in the party. ${ }^{19}$ Former Oklahoma Congressman Mickey Edwards supports the calls for primaries designed to produce more moderate candidates. While speaking at an Intelligence Squared US debate, he said, "It's the primary system where the Republican activist, the true believers, people like you [a social conservative] show up. And what happens is you end up with nominees like Christine O'Donnell..." He goes on to say that radicals running for office is "what's killing the party." 20 Such a change obviously angers social conservatives who believe their candidates represent winnable politicians. Similarly, public figures such as Rick Santorum equate potential Republican acceptance of gay marriage with assured electoral defeat as well as an invitation to create a new political party. ${ }^{21}$ Thus, the social conservative movement has come full circle - apolitical prior to the radical 1960s, extremely politically powerful throughout the 1980 s and early 2000s, and now a tumor within the Republican Party. Attacks from "the Establishment" on the social conservatives did not stop with the publication of the report. Perennial Republican Karl Rove, widely regarded as a highly influential party member, 
sponsored the development of the Conservative Victory Project. Tired of losing seemingly winnable races because of primaries producing extremist Republicans, Rove's project, in the words of Kevin Cirilli of Politico, sought to, "...go after certain conservative grass roots efforts."22 Beyond being blamed by many Republicans for spoiling their chance at the White House, the "establishment" now seems to be actively trying to prevent social conservatives from even running for political office. These accounts demonstrate the dramatic and ongoing separation of social conservatives from the main players in the Republican Party. In the past, the group primarily only struggled with non-Republicans while the GOP found a way to include them in the conservative battle. "Establishment" attacks confirm that social conservatives now have to worry about isolation from the GOP as well. Additionally, the attacks represent how 2012 served as a landmark cycle in regards to the formation of a social conservative counterpublic.

\section{CONTINUED EXAMPLES OF SEPARATION}

The strain on the GOP-social conservative relationship serves as excellent evidence for the separation component of the counterpublic definition. Recent cultural events have deepened the divide between the two coalitions. As immigration reform and the discussion on gay marriage have gained national media coverage in the aftermath of the election, the wedge dividing the ideology camps has significantly deepened. For some on both sides complete separation represents the only viable option. David Brooks, columnist for The New York Times, envisions a GOP division occurring along geographical lines, creating a coastal and Midwestern party in addition to a Southern and Western party. He views this as a necessary step in making the Republican message relevant again in a period in which they have lost the popular vote in five of the last six Presidential elections. ${ }^{23}$ Others believe the divisional fence should be drawn according to policy lines as seen by younger Republicans' more favorable stance towards Ohio Senator Ron Portman's support of gay marriage. ${ }^{24}$ For example, one writer, Mark Chaves, rejected his evangelical base in his youth as a result of its affiliation with rigid conservative policies. Chaves now checks unaffiliated when asked for his religious status because of the group's perception of gay marriage and the general LGBT community. ${ }^{25}$ For fifty years, in Daniel William's view, author of God's Own Party, social conservatives have maintained close ties to the Republican Party "because the GOP shared their vision of a 'Christian' nation resolutely defending itself against internal and external enemies." ${ }^{26}$ Given that voters have questioned the GOP's devotion to the maintenance of a strict 'Christian' nation, how will the Republican Party respond? Will shifts toward the center on social issues increase their standing with independents or destroy their base? Members of the Republican team, such as former Republican Senator John Danforth, seek to free the party from the Religious Right's conservative tug. An ordained Episcopal minister, Danforth is, according to Lambert, "critical of the Religious Right primarily because of what he considers to be its negative influence on the GOP." ${ }^{27}$ The social conservative response to questions of this sort has been consistent - though the times may be changing, sticking to conservative principles will provide the GOP with the easiest path to victory. Such a position, founded upon the idea of political power, again shows how social conservatives reject an inferior role. 


\section{RELIGIOUS LEADERS’ MEDIA EMPIRES AND THE CIRCULATION OF TEXTS}

Various media networks, espoused by religious figures, facilitate the spread of literature crucial to the survival of a subaltern discourse. Broadcasts of the leaders' responses to the 2012 election represent the social conservative narrative that America, with its morality in steep decline, has become 'lost'. Their dedication to their core beliefs has increasingly made them a counterculture in the American political universe. Using email, TV, editorials, and speeches to convey their narrative, this isolationist approach has solidified their power over the Republican Party's future due to the loyalty exhibited by their followers. In Religion in America, Lambert summarizes, "Dissatisfied with the mainstream media that Conservative Christians believed expressed humanist ideas and ridiculed Christian principles, the Religious Right has developed an alternative media that advances their views." ${ }^{28}$ In addition to normal media, reverends have the unique ability to connect with voters during a special time in their week: Sabbath. Megachurches, almost entirely Protestant, have made an increasingly large political impact as the number of churches (with at least 2,000 attendees) has soared from 50 in 1970 to 1,300 in 2009. ${ }^{29}$ Progressive \& Religious describes the social conservatives' prominent media presence. Author Robert Jones cites James Dobson, founder of Focus on the Family (FOF), as an example of the networks many reverends have established. With 2.3 million magazine subscribers, a radio program carried by more stations than National Public Radio, and more monthly readers than The New York Times Dobson possess a media empire. ${ }^{30}$ Such an empire can have an extensive impact on the electoral process. Some, like Daniel Williams, speculate that access to a portion of this network allowed Mike Huckabee to win a number of early primaries in the 2008 election cycle. Williams points out that Huckabee received the emails of 414,00o young evangelicals in Iowa from a local evangelical leader prior to the state's primary: a contest he won. ${ }^{31}$ This substantial contact sheet emphasizes the power of access to such a tight network of voters. These networks also aid with political messaging. Immediately following the 2012 Presidential Election, Ted Haggard, an evangelical Pastor with immense popularity, used his blog to comment on the disappointing loss. Rather than acknowledge Obama's well-run campaign or Romney's inability to connect with average voters, Haggard said, "I think Obama won the election primarily because his culture was more appealing to most Americans." Haggard claims Americans embraced Obama's past use of drugs and alcohol and that specific political positions "were not the determining factors in the election." 32 In the opinion of people like Haggard, Americans no longer prioritize strong morals contributing to the nation's deterioration. Refusing to change his political views in correspondence with the majority of Americans, Haggard also embodies the message centered upon defiance to policy change. Reverend Albert Mohler Jr., President of the Southern Baptist Theological Seminary, shares Haggard's disappointment in American morality. In an interview shortly after the election, Reverend Mohler used the opportunity to start building upon the narrative of a 'lost' America. Acknowledging that they did get their anti-abortion, anti-same-sex marriage message out, he laments, "An increasingly secularized America understands our positions, and has rejected them." 33 Instead of perceiving the electoral loss as a sign of required reform, these central social conservative figures have used the results as a symbol of American moral depravity. Ralph Reed, an early leader in the Christian Coalition, renounces efforts by 'the Establishment' to moderate its stance to increase voter appeal. Displaying the movement's rebellious attitude, Reed argues, "We've been hearing the same old song [for change] for 30 years." 34 Additionally, Reed founded 
Families of Faith, an organization that has worked tirelessly to promote the narratives of America needing 'saving' and the importance of remaining steadfast in support of conservative principles. At an April 2013 debate with David Brooks, Reed gave an explicit vision of the Republican Party from a social conservative's perspective. "The fact of the matter is what the Republican Party stands for, what it fights for and what it seeks to advance," in Reed's opinion, "is policies that will strengthen marriage, family, childbearing and rearing." 35 According to Reed, the GOP is synonymous with conservative principles, a distinction increasingly at odds with the rest of the Party's members. Clearly, to social conservatives, the GOP must play a role in rescuing America from moral decline. This objective conveys how these narratives are heavily based on social conservatives having a persistent role in American political discourse. The necessity of a vibrant Religious Right serves as the movement's reasoning behind rejecting subordination.

\section{THE MEDIA'S CONTRIBUTION TO THE DISPERSAL OF THE NARRATIVES}

A narrative based on a 'lost' America has taken hold throughout social conservative camps and has further alienated them by preventing them from shifting their views. So although the majority of Americans, according to a Wall Street Journal poll from March 2013, now support gay marriage and legalized abortions in most cases, social conservatives will not budge. ${ }^{6}$ TV personalities have assumed this defiant narrative as well. The dissemination of these narratives over another media outlet illustrates the wide reach of the social conservatives' circulation of ideas. Depressed by the Presidential election defeat, Mike Huckabee issued a statement to his attentive social conservative audience through his blog, podcast, and radio outlets. Like the evangelical ministers, Huckabee purports America's primary problems are spiritual but that as a body, social conservatives must not give up the fight. He urges his followers to "...gear up and get ready for the next battle. That's what we do as people of faith and a party of principle. We don't stop believing what we believe. We do a better job of doing what we're supposed to do. That is how you save America from herself." ${ }^{37}$ In this message Huckabee reinforces the narratives of both defeat and defiance through his stubborn refusal to accept an America with 'immoral' standards. According to Huckabee, American can be 'saved' but it will require the social conservative movement to stick to its principles and remain cohesive. To prove his recognition of the Religious Right as vital body, Huckabee asserts that they still have the potential to alter America's course. Likewise, Bill O’Reilly has used his position as a Fox News TV personality to share the narrative of America's moral defeat and the duty of Republicans to prevent it. Pew data from May 2011 state that a remarkable 54 percent of all staunch conservatives regularly watch Fox News. ${ }^{8}$ Such a connected audience undoubtedly helps TV personalities spread their message. Analysis of O'Reilly's show helps to further define the social conservative narrative. He urges his viewers to "...convince younger Americans, minorities and apathetic people of which there are plenty that the country is heading for disaster." Focusing on minorities, the young, and the unreligious, O'Reilly demonstrates the movement's inability to communicate with a large portion of the population. Such a narrow, albeit focused, reach helps clarify the origin of the movement's tenseness with several American demographics.

Both Huckabee and O'Reilly rely on dramatic rhetoric to keep their followers dedicated to the cause. Religious figures cite the prospect of going to Hell as motivation to preach conservative values. On The Bill O’Reilly Factor episode covering the apparent culture war 
raging in the United States, O’Reilly presents another apparently awful possibility: "If traditional people don't begin standing up we will become Sweden. No question about it."39 To social conservative leaders there is no middle ground: America will either be saved or damned to Sweden-hood. A notorious radio personality, Rush Limbaugh, shares O’Reilly's concern regarding American morality. Using the same polarizing diction as O'Reilly, Limbaugh worries that the Obama administration seeks "to effectively erase the 2,000 years of Judeo-Christian values as a governing force, as a positive influence on cultures and society." 40 Statements like this solidify the idea of America being forced away from its Christian base. Progressives seized the White House and now threaten to destroy the Christian role in the US government. These TV personalities have fully embraced both narratives, which ensure their pious followers will as well.

\section{POLITICIAN'S REFUSAL TO ACCEPT LESS INFLUENCE}

Elected officials advanced the narratives and continually voice their faith in the social conservative's ability to make a difference. Disregarding the polls and statistics, Presidential candidate Rick Santorum asserts, "If we had candidates in the last two presidential elections who weren't ashamed of the positions they had on these issues and played offense, instead of listening to the same people who now want to abandon the issues, we would've been successful." ${ }^{11}$ Calling for Republicans to stand up to those opposed to their moral beliefs, Santorum personifies the social conservatives' rejection of any suggestion to alter their principles. Moreover, the Pennsylvania Senator's remarks indicate that social conservative leaders have spurned subordinate status. Lindsay Graham, an influential Republican senator, recently displayed the difficultly 'the Establishment' is having with the social conservatives. As Ed O'Keefe reported, Graham has allowed the faction to maintain its narrative. Although Graham did ask the Religious Right to re-word their messaging at a recent Republican meeting in South Carolina, he admitted that members of the far right "don't have to be embarrassed about [their] social conservatism." 42 As the election results suggest, the GOP's platform could apply to a broader cross-section of Americans if the whole party allowed for slightly more progressive stances. However, the narrative of defiance and defeat defines the Religious Right, leaving the rest of the party with few options. GOP politicians from the House to the Senate have failed to persuade the coalition to consider any other narrative. Recently, Herman Cain, a Republican Presidential candidate, made the group's defiance explicit. Immediately after the election results became official, Cain encouraged the creation of a third party of true conservatives. His idea represents the devotion of the movement to retaining its ideological base. Cain's support of such a drastic measure emphasizes the Religious Right's zealousness and confidence in their timeless political impact. Reverends, personalities, and politicians have utilized the same strategies in developing the narrative. Echoing O'Reilly's dire predictions, Texas Senator Ted Cruz said the movement has the choice between "surrendering or standing up now to defend our liberty." This statement led to massive rounds of applause at the Conservative Political Action Conference signifying the general receptiveness towards an uncompromising path forward. 43 These politicians likely remember how well this narrative worked in the 2004 election. "I Vote Values" embodied the narrative of defiance and defeat for the Republican Party in 2004. The phrase painted an image of an American in need of superior values and signified Republican refusal to place social matters on the political back burner. Author Robert Jones had 
an interesting interpretation of the strategy. For Jones, “The genius of this bold plan was to brazenly claim all of religion and morality for one party and to radically contract the scope of these terms to a few narrow wedge issues such as abortion, same-sex marriage, and embryonic stem cell research." 44 It appears social conservatives still consider the use of the same plan vital to 'saving' America. Just as they did when fighting for George W. Bush's re-election, social conservatives have relied on a negative narrative to inspire action. Wald mirrors this sentiment when he argues that Republican candidates rely on social conservatives to turn out at the polls. GOP politicians have, as Wald observed, sought the traditionalist vote by implementing their narrative. "By blaming liberal programs...for breaking down family structure, fueling a rise in crime, and undermining the social order," Wald thinks, "Republican campaign themes have echoed the language of the Christian right." 45 The idea of a collapsing social structure based on family values represents the core essence of both the narrative of America's defeat and the need to fight for conservative ideals. The past successes of the social conservatives may explain why most have not accepted the idea of being beneath any governmental faction. Political scientist Matthew Moen concurs that the Religious Right's adoption of 'victimization' rhetoric has been used "as a clever and calculated ploy to tap the reservoir of positive sentiment for victims of American society." 46 These leaders have efficiently delivered this message to millions and include heated diction to ensure that their followers and the American public take the message seriously. Likewise, stressing the public's need for salvation courtesy of the social conservatives, organizers of the movement have successfully woven the theme of political relevancy into their narratives.

\section{HOW EVERYDAY SOCIAL CONSERVATIVES ADOPTED THE NARRATIVES}

Common social conservatives also promote both narratives. They bolster the narratives through their undying support for conservative politicians, solely watching Fox News, and buying their reverend's books, magazines, and podcasts. When NBA player Nick Collins came out as the first declared homosexual athlete in the league, it led to more people questioning the evangelical stance towards the LGBT community. However, for typical social conservatives, "their sense of persecution," according to John Blake of CNN, "goes beyond their stance of homosexuality." Blake's recent article outlines how the narrative of opposition to policy alterations amidst America's secularization has clearly led to the augmentation of pressure with the public. A few organizations, such as the Southern Poverty Law Center, have even labeled evangelical groups like the Family Research Council as "hate groups." 47 This serves as an example of the extreme tension that has increasingly manifested itself through cultural events. In response to these harsh distinctions, leaders have continually maintained the need to fight back in this cultural war.

\section{SOCIAL CONSERVATIVES WHO FEEL SUBORDINATE}

Others take the narrative of defeat to the next level; they view America's secularization as foreshadowing the end of social conservatives' political influence. In essence, they accept the subordination generally assigned to countercultures. Writing a month after the election, John S. Dickerson, an evangelical Pastor from Arizona, tried to summarize the effect of the religious right on voters. Unlike many, he felt social conservatives had little impact on the Republican primaries or the general election. Furthermore, the fundamental changes in American culture 
suggests “...that the structural supports of evangelism are quivering...” Dickerson mentions an aging congregation, failure to react to cultural shifts, and shrinking church attendance as indicators of evangelicalism's inability to ever return to the political height it reached in 2004. Opposing Warner's model, most other social conservatives remain steadfast in their belief that they can reclaim the political high ground, assuming they do not stray from the righteousnessbased path they have frequently followed. In his summary, Dickerson asserts, "Strategies that served evangelicals well just 15 years ago are now self-destructive. The more that evangelicals attempt to correct the course, the more they splinter their movement. In coming years we will see the old evangelicalism whimper and wane."48 Although many, such as Dickerson, have suggested that evangelism as a political force will end sooner rather than later, Chris Hedges' investigation into the movement suggests otherwise. Hedges points out, "But within this mass of divergent, factitious and varied group [of evangelicals] is this core group of powerful Christian dominationists who have latched on to the despair, isolation, disconnectedness and fear that drives many people into these churches." 49 Similarly to Dickerson, Hedges tends to disagree with the social conservative movement's narratives, but his analysis references the continual strength produced by their negative message.

\section{POWER GARNERED FROM STUBBORNESS}

Appeasing Republican leadership by becoming a lesser player and willingly submitting to the findings of the Growth and Opportunity Project would likely help Republicans nationally compete for independent voters. However, the acceptance and spread of the two related narratives mentioned above has given the social conservative movement power as a result of their unity. Writing for The Washington Post, Greg Sargent mentions, "Social conservatives remain a large and powerful part of the Republican coalition. They provide donors and volunteers, and they are the driving push behind the GOP's nationwide effort to pass state-level abortion restrictions..." 50 Sargent's analysis displays the utility of the social conservatives to the larger Republican movement. Similarly, Ralph Reed questions those Republicans who want to "give the cold shoulder to evangelicals and other voters of faith who make up the overwhelming majority of their voters." ${ }^{1}$ Although some debate just how influential evangelicals are on election results, losing the social conservative faction would likely injure the Republican Party's numbers. Through studying the research of Sociologist Kenneth Wald, Lambert came to the same conclusion. While some evidence does suggest evangelicals make an impact on how people vote, "perhaps the biggest impact of the Religious Right is voter turnout." 52 To Lambert and many others, social conservative consensus and democratic participation fuels their political power.

\section{SUMMARY OF SOCIAL CONSERVATIVE'S HOSTORY}

The social conservative movement represents a body of primarily white, older evangelical individuals affiliated with the Republican Party who reside in the South. After gaining political influence in the 1970s, the group has increasingly played a role in determining Republican platforms and Presidential candidates. However, their staunch refusal to allow for the secularization of the party in accordance with the general US population has led to creation of a counterpublic within the greater Republican Party. Social conservatives acknowledge their subordinate status but have bound together as a result of the circulation of common ideas from 
Reverend to media to politician. Some blamed the group for Mitt Romney's loss as well as dismal performances in a number of Senate races, which fostered the development of two narratives within the social conservative coalition. More specifically, representatives of social conservatism at churches, on the airwaves, and in Washington D.C. have created a narrative of a 'lost' America that requires saving which their movement can provide if they keep their values.

\section{FUTURE OF SOCIAL CONSERVATIVES}

The next election should show whether the leaders of the social conservative movement, in choosing to steadfastly remain true to their stances on social issues, selected the correct course of action. In the short term, the maintenance of the narrative of moral defeat and of defiance has bolstered the movement's solidarity and electoral importance in a time of external pressure to conform to new American values. While other groups may have taken the prescribed route of subordination, social conservatives have relied on their narratives to prove why they matter. Lambert maintains that both religionists and secularists alike often "oppose the exclusivism of any group that purports to speak for all Americans on moral issues." 53 This analysis implies that social conservatives will undoubtedly face steep challenges as they try to lead all Americans in the culture war. Recent Republican history demonstrates the difficulty associated with denying the wants of the social conservatives. In 1992, the GOP faced a similar situation: they had the opportunity to create a new image for the Party while creating its official platform. In the words of the authors of The God Strategy, they choose to, "...mobilize the base of the religious conservatives that had been built over the past 12 years." 54 Arguably, the social conservative base is even broader today; will the Party side with them again?

\section{REFERENCES}

Abdullah, Halimah. CNN, "Portman reversal highlights GOP generational split." Last modified March 15, 2013. Accessed April 23, 2013. http://www.cnn.com/2013/03/15/politics/ portman-reax.

Blake, John. CNN, "When Christians become a 'hated minority." Last modified May 5, 2013. Accessed May 5, 2013. http://religion.blogs.cnn.com/2013/05/05/when-christiansbecome-a-hated-minority/?hpt=hp c1.

Bogan, Jesse. Forbes.com, "America's Biggest Megachurches." Last modified June 26, 2009. Accessed April 23, 2013. http://www.forbes.com/2009/06/26/americas-biggestmegachurches-business-megachurches.html.

Bouie, Jamelle. "For the GOP, social conservatives aren't the only problem." The Plum Line (blog), April 1, 2013. Accessed April 23, 2013. http://www.washingtonpost.com/ blogs/plum-line/wp/2013/o4/o1/for-the-gop-social-conservatives-arent-the-onlyproblem/

Brooks, David. The New York Times, "A Second G.O.P." Last modified January 28, 2013. Accessed April 23, 2013. http://www.nytimes.com/2013/01/29/opinion/brooks-asecond-g-o-p.html? $\mathrm{r}=1 \&$. 
Chaves, Mark. 2011. American religion: contemporary trends. Princeton, N.J.: Princeton University Press.

Cirilli, Kevin. Politico, "Haley Barbour disputes Crossroads report." Last modified April 11, 2013. Accessed April 23, 2013. http://www.politico.com/story/2013/o4/haley-barbourcrossroads-karl-rove-89936.html.

Cruz, Ted. "Ted Cruz at CPAC" Recorded March 16 2013. The Washington Post. Web

Dickerson, John. The New York Times, "The Decline of Evangelical America." Last modified December 15, 2012. Accessed April 23, 2013. http://www.nytimes.com/2012/12/16/ opinion/sunday/the-decline-of-evangelical-america.html?pagewanted=all\&_r=1\&.

Domke, David Scott, and Kevin M. Coe. 2008. The God strategy: how religion became a political weapon in America. Oxford: Oxford University Press.

Edwards, Mickey. "The GOP must seize the center or die" Recorded April 17 2013. Intelligence Squared U.S. April 17 2013. Web, http://www.intelligencesquaredus.org/images/debates/past/transcripts/o41713 gop.pdf.

Goodstein, Laurie. "Christian Right Failed to Sway Voters on Issues." New York Times 9 Nov. 2012, sec.U.S.: n. pag.nytimes.com. Web. 23 Apr. 2013.

Haggard, Ted. "Our Re-Election of President Obama."Official blog of Ted Haggard (blog), November 27, 2012. Accessed April 23, 2013. http://tedhaggardblog.com/2012/11/27/ our-re-election-of-president-obama/

Hedges, Chris. 2007. American fascists: the Christian Right and the war on America. New York: Free Press.

Huckabee, Mike. mikehuckabee.com, "Statement On The Election." Last modified Novemebr 7, 2012. Accessed April 23, 2013. http://www.mikehuckabee.com/mike-huckabeenews?ID=76018c9d-b69b-4bd3-9f50-ab6229e1cac5.

Jones, Jeffrey. Gallup, "Americans Now Say Gov't Should Not Favor Any Set of Values." Last modified October 10, 2012. Accessed April 24, 2013. http://www.gallup.com/poll/ 157958/americans-say-gov-not-favor-set-values.aspx.

Jones, Jeffrey. Gallup, "In U.S., Nearly Identify as Economically Conservative." Last modified May 05, 2012. Accessed April 23, 2013. http://www.gallup.com/poll/154889/NearlyHalf-Identify-Economically-Conservative.aspx. 
Jones, Robert P. 2008. Progressive \& religious: how Christian, Jewish, Muslim, and Buddhist leaders are moving beyond the culture wars and transforming American life. Lanham, Md: Rowman \& Littlefield Publishers.

Lambert, Frank. 2008. Religion in American politics: a short history. Princeton: Princeton University Press.

Lee, MJ. Politico, "Poll: Social Issues Last on Voter's List." Last modified Feburary 2, 2012. Accessed April 23, 2013. http://www.politico.com//news/stories/0212/73447.html.

"Lift Every Voice." The Economist, May 5, 2012. Accessed April 23, 2013. http://www. economist.com/node/21554201

Limbaugh, Rush. Fox News, "The Rush Limbaugh Show." Last modified April 4, 2013. Accessed May 5, 2013. http://www.rushlimbaugh.com/daily/2013/04/08/us army training_instructor_classifies_catholics_evangelicals_as_extremists_like_alqaeda_ha mas.

Martin, Jonathan. Politico, "Social conservatives fight back." Last modified April 1, 2013. Accessed April 23, 2013. http://dyn.politico.com/printstory.cfm?uuid=0A415242-2A904E7D-82B2-8D8645F76B3F.

Martin, Jonathan and Maggie Haberman. Politico, "Right blasts RNC 'autops'y as power grab." Last modified March 18, 2013. Accessed April 23, 2013. http://www.politico.com/story/ 2013/o3/rnc-autopsy-may-rile-up-base-89010.html.

Murray, Mark. NBC, "Majority, for first time, want abortion to be legal." Last modified January 21, 2013. Accessed April 23, 2013. http://firstread.nbcnews.com/ news/2013/01/21/ 16626932-nbcwsj-poll-majority-for-first-time-want-abortion-to-be-legal?lite.

Newsmax, "Ralph Reed to GOP: Don't Take Election Losses Out on Social Conservatives." Last modified November 26, 2012. Accessed April 23, 2013. http://www.newsmax.com/US/ reed-faith-freedom-election/2012/11/26/id/465323

O'Keefe, Ed. "GOP rifts exposed in South Carolina." The Washington Post, Evening Edition edition, sec. Politics, May 4, 2013. Accessed May 4, 2013. www.washingtonpost.com

O'Reilly, Bill. Fox News, "The Culture War Goes Worldwide." Last modified January 15, 2013. Accessed April 23, 2013. http://www.foxnews.com/on-air/oreilly/2013/01/16/billoreilly-culture-war-goes-worldwide.

PBS, "God in America: "Of God and Caesar"." Last modified October 11, 2010. Accessed April 23, 2013. http://www.pbs.org/godinamerica/transcripts/hour-six.html.।

Pew Forum, "U.S. Religious Landscape Survey." Last modified 2010. Accessed April 23, 
2013. http://religions.pewforum.org/maps.

Pew Research Center , "Beyond Red vs. Blue: The Political Typology." Last modified May 04, 2011. Accessed April 23, 2013. http://www.people-press.org/2011/05/o4/section-3demographics-and-news-sources/.

Reed, Ralph. "The GOP must seize the center or die" Recorded April 17 2013. Intelligence Squared U.S. April 17 2013. Web, http://www.intelligencesquaredus.org/images/ debates/past/transcripts/o41713 gop.pdf.

Smidt, Corwin E. 2010. The disappearing God gap?: religion in the 2008 presidential election. Oxford: Oxford University Press.

"Votes and prayers." The Economist, 11 8, 2012. Accessed April 23, 2013. http://www.economist.com/blogs/graphicdetail/2012/11/daily-chart-2

Wald, Kenneth D. and Allison Calhoun-Brown. 2011. Religion and politics in the United States. Lanham, Md: Rowman \& Littlefield Publishers.

Williams, Daniel K. 2010. God's Own Party: the making of the Christian right. Oxford: Oxford University Press.

Wing, Nick. The Huffington Post, "Rick Santorum: It Would Be 'Suicidal' For GOP to Embrace Gay Marriage." Last modified April 9, 2013. Accessed April 23, 2013. http://www.huffingtonpost.com/2013/04/08/rick-santorum-gop-gaymarriage n 3040225.html.

Zeleny, Jeff. "Iowa May Turn G.O.P.'s Focus to Social Issues." The New York Times. March 26, 2011. Accessed April 23, 2013.http://www.nytimes.com/2011/03/27/us/politics/ 27iowa. html?pagewanted=all\&_r=1\&

\section{NOTES}

${ }^{1}$ Warner, Michael. 2002. Publics and counterpublics. New York: Zone Books

${ }^{2}$ Ibid., 56.

3 Ibid.,118.

4 "Lift Every Voice." The Economist, May 05, 2012. Accessed April 23, 2013. http://www.economist.com/node/ 21554201

5 "Votes and Prayers" November 08, 2013

6 "Beyond Red vs. Blue: The Political Typology" May 04, 2011

7 “In U.S., Nearly Half Identify as Economically Conservative," last modified May 25, 2012, http://www.gallup.com/ poll/154889/Nearly-Half-Identify-Economically-Conservative.aspx 
8 “U.S. Religious Landscape Survey," last modified 2010, http://religions.pewforum.org/maps

9 Smidt, Corwin E. 2010. The disappearing God gap?: religion in the 2008 presidential election. Oxford: Oxford University Press, 65.

10 "Votes and Prayers," The Economist, November 08, 2013, http://www.economist.com/blogs/graphicdetail/2012/ 11/daily-chart-2

${ }^{11}$ Jones, Robert P. 2008. Progressive \& religious: how Christian, Jewish, Muslim, and Buddhist leaders are moving beyond the culture wars and transforming American life. Lanham, Md: Rowman \& Littlefield Publishers, 10.

12 Lambert, Frank. 2008. Religion in American politics: a short history. Princeton: Princeton University Press, 190.

13 “God in America: Of God and Caesar," last modified October 11, 2010, http://www.pbs.org/godinamerica/ transcripts/hour-six.html

14 Wald, Kenneth D., and Allison Calhoun-Brown. 2011. Religion and politics in the United States. Lanham, Md: Rowman \& Littlefield Publishers.

15 “God in America: Of God and Caesar"

16 “Iowa May Turn G.O.P.'s Focus to Social Issues,” last modified March 26, 2011, http://www.nytimes.com/ 2011/o3/27/us/politics/27iowa.html?pagewanted=all\&_r=1\&

${ }_{17}$ Jones, Jeffrey. Gallup, "In U.S., Nearly Identify as Economically Conservative." Last modified May o5, 2012.

18 "Poll: Social Issues Last on Voter's List", last modified February 2, 2012, http://www.politico.com//news/stories/ 0212/73447.html

19 "Right blasts RNC 'autopsy' as power grab”, last modified March 18, 2013.

http://www.politico.com/story/2013/03/ rnc-autopsy-may-rile-up-base-89010.html

${ }^{20}$ Edwards, Mickey. "The GOP must seize the center or die" Recorded April 172013.

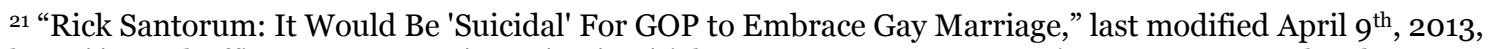
http://www.huffingtonpost.com/2013/o4/o8/rick-santorum-gop-gay-marriage_n_3040225.html

22 “Haley Barbour Disputes Crossroads Report," last modified April 11, 2013,

http://www.politico.com/story/2013/o4/ haley-barbour-crossroads-karl-rove-89936.html

23 “A Second G.O.P.," last modified last January 28, 2013, http://www.nytimes.com/2013/o1/29/opinion/brooks-asecond-g-o-p.html?_r=1\&

24 "Portman Reversal highlights GOP generational split," last modified March 15, 2013, http://www.cnn.com/ 2013/o3/15/politics/portman-reax

25 Chaves, Mark. 2011. American religion: contemporary trends. Princeton, N.J.: Princeton University Press.

${ }^{26}$ Williams, Daniel K. 2010. God's Own Party: the making of the Christian right. Oxford: Oxford University Press, 270.

27 Lambert, Religion in America, 213.

${ }^{28}$ Lambert, Religion in America, 217.

29 “America’s Biggest Megachurches," last modified June 26, 2009, http://www.forbes.com/2009/o6/26/americasbiggest-megachurches-business-megachurches.html

${ }^{30}$ Jones, Progressive \& religious, 4.

${ }^{31}$ Williams, God’s Own Party, 272. 
32 "Our Re-Election of President Obama," last modified November 27, 2012, http://tedhaggardblog.com/2012/11/27 /our-re-election-of-president-obama/

33 "Christian Right Failed to Sway Voters on Issues," last modified November 9, 2013, http://www.nytimes.com/ 2012/11/10/us/politics/christian-conservatives-failed-to-sway-voters.html?ref=evangelicalmovement\&_r=1\&

34 "Social Conservatives fight back," last modified April 1, 2013, http://dyn.politico.com/printstory.cfm?uuid=o A415242-2A90-4E7D-82B2-8D8645F76B3F

35 Reed, Ralph. "The GOP must seize the center or die" Recorded April 172013.

36 "Majority, for first time, want abortion to be legal," last modified, January 21, 2013, http://firstread.nbcnews.com/ _news/2013/o1/21/16626932-nbcwsj-poll-majority-for-first-time-want-abortion-to-be-legal?lite

37 "Statement On The Election," last modified November 7, 2012, http://www.mikehuckabee.com/mike-huckabeenews?ID=76018c9d-b69b-4bd3-9f50-ab6229e1cac5

38 "Beyond Red vs. Blue: The Political Typology."

39 “The Culture War Goes Worldwide," last modified January 15, 2013, http://www.foxnews.com/onair/oreilly/2013/ 01/16/bill-oreilly-culture-war-goes-worldwide

${ }^{40}$ Limbaugh, Rush. Fox News, "The Rush Limbaugh Show." Last modified April 4, 2013.

41 "Social Conservatives fight back," last modified April 1, 2013

$4^{2}$ O'Keefe, Ed. "GOP rifts exposed in South Carolina." The Washington Post, Evening Edition edition, sec. Politics, May 4, 2013. Accessed May 4, 2013. www.washingtonpost.com

43 Cruz, Ted, "Ted Cruz at CPAC," Web.

44 Jones, Progressive and Religious, 5.

45 Wald, Religion and Politics, 222.

${ }^{46}$ Lambert, Religion in American Politics, 210.

47 Blake, John. CNN, "When Christians become a 'hated minority." Last modified May 5, 2013.

48 “The Decline of Evangelical America," last modified December 15, 2013, http://www.nytimes.com/2012/12/16/ opinion/sunday/the-decline-of-evangelical-america.html?pagewanted=all\&_r=1\&

49 Hedges, Chris. 2007. American fascists: the Christian Right and the war on America. New York: Free Press.

50 Janelle Bouie, "For the GOP, social conservatives aren't the only problem," The Plum Line (blog), April 1, 2013, http://www.washingtonpost.com/blogs/plum-line/wp/2013/o4/o1/for-the-gop-social-conservatives-arent-the-onlyproblem/

51 "Ralph Reed to GOP: Don't Take Election Losses Out on Social Conservatives," last modified November 26, 2013, http://www.newsmax.com/US/reed-faith-freedom-election/2012/11/26/id/465323\#ixzz2QlsPsJxd

${ }^{2}$ Lambert, Religion in America, 217.

53 Lambert, Religion in American Politics, 209.

54 Domke, David Scott, and Kevin M. Coe. 2008. The God strategy: how religion became a political weapon in America. Oxford: Oxford University Press, 131. 